\title{
Multiple Religious Belonging: Path-of-Life-Navigation and Spiritual Identity*
}

\author{
Martin Rötting \\ Paris Lodron Universität, Salzburg, Austria
}

\begin{abstract}
Multiple Religious Belonging is a type of spirituality that needs to be analyzed. This article makes use of a model that understands spiritual identity as Pafh-of-Life-Navigation and applies this to the question why those who identity themselves as multiple religious belongers navigate their spiritual life in a special way. The article argues that using the model helps to understand this special kind of spiritual identity and can set it into the context of a pluralistic world of spiritual meanings that individuals have to connect to networks of meanings. The question how two spiritual ideations make sense is tackled and answered by introducing the anamorphic points of reference in use. Multiple identity is a form of navigation using two instead of one map and making use of the difference between these for meanings as a force to proceed forward. In that way, how individuals use the tension between two historically, socially and spiritually constructed identities is in itself part of their identity process.
\end{abstract}

Keywords: identity, multiple religions, patchwork, spirituality

This article aims to analyze the interesting phenomena of multiple religious belonging. While others, among them Rose Drew (2011), Michael Amaladoss (2002), and Michael von Brück (2007), have tackled this topic already, often in the light of a theological horizon, here I intend to focus on the question of multiple religious belonging with a religious studies perspective of spiritual identity as a way-of-life-navigation. ${ }^{1}$ In this way I hope to understand better why individuals seem to benefit of an identity, which keeps more than one religion active in their faith narratives.

Before going into the topic itself, we have to ask questions about the terms: (1) religion and spirituality, which have both become so debated, that one has to be clear how they are used in a study. (2) After this the theory of spiritual identity as way-of-life-navigation is introduced. This then makes it possible to investigate if (3) multiple religious belonging is a form of navigation using two instead of one map. The hypothesis is tested by (4) looking at identity sets and the anamorphic point, a term used to mark a specific phase in the identity process. Finally I try to use the presented arguments in order to answer the question: if a (5) multiple religious identity should be seen as "way" or "goal" in a religious studies point of view.

\section{Religion vs. Spirituality?}

Processes of migration and globalization lead to the fact that meanwhile the most different religious world

\footnotetext{
* This article was in a first version given as a paper at the European Academy of Religion in Bologna on a panel of the European Network of Buddhist-Christian Studies with the title Buddhist-Christian Dual Belonging: A Contested Phenomenon in March 6th 2018. I want to thank Graham Wiseman for his suggestions and corrections.

Martin Rötting, Dr., Asst.-Prof., Religious Studies, Paris Lodron Universität, Salzburg, Austria.

${ }^{1}$ On parts of this paper I draw on revised chapters and parts of my study on spiritual identity (Rötting, 2019a).
} 
views are not only known as fact, but also ${ }^{2}$ available as religious option. As Peter Berger (2015) emphasizes, the all too woodcut-like thesis of secularization as the disappearance of religion must be revised, but the effects of secularization processes, such as pluralization and individualization, in society nevertheless exist. This would lead to a need to choose.

The more diverse the religious environment, the higher, of what may be called the effort of appropriation of spiritual identity becomes.. What is understood today as spirituality is fed by several sources, such as that of the French Christian religious tradition and that of the English-speaking New Age and esoteric movement. ${ }^{3}$ Heterogeneous influences on the term have extended it to such an extent that a definition of "spirituality" and thus also of "spiritual identity" seems difficult. However, one often encounters a use in which religion rather means "organization" and "tradition" and spirituality means "concrete practice" in relation to the experience of the subject with possible connections to spiritual traditions, which of course can refer to concrete religions or alternatives.

The term "spirituality" is differently used in cultures. Some seem to have adapted the "globalist" form and use it is across religious traditions and in connection with traditional and modern forms of religions. Others seem to bind it back to more traditional wordings. Research in Lithuania indicated (Rötting, 2019b) that people tend to "catholize" the usage and replace "dvasingumas" (spirituality) with "tikaimas" (believe, faith) if asked about their "spirituality". Whereas in Korea even Buddhists are using the Christian term "Yongsong" (영성) when asked about "spirituality" in many religious settings.

\section{Spiritual Identity: A Narrative of Life-Way-Navigation}

The model (Rötting, 2019b) I have developed is based on my empirical data and a theory constructed by using the work of Paul Ricoeur, Peter Burke, and Heiner Keupp. Following Paul Ricoeur (and others), spiritual identity can be understood narratively. It arises through narrative processes of re-figuration and presents itself as a narrated story. Ricoeur (1988), unlike others, emphasizes that life itself is not already in narrative structure, but that our actions are a kind of pre-structuring of directionality, intention, and goal guidance.

In continuation of the Identity Theory developed by Peter Burke and his colleagues, spiritual identity can also be seen as a function of the self that interprets situations in order to make people capable of action (Burke \& Stets, 2009). Different roles are addressed with different Identity Sets, which, depending on the situation and context, are used in a hierarchical order to interpret reality.

Heiner Keupp (1999) showed that identities in late modernity have patchwork-like structures and are "assembled" in order to be able to respond to new situations.

With these strands offered by identity research, a model of spiritual identity as life-path navigation developed on the basis of the narratives of the interviews emerges. The approach of religious studies tries to describe spiritual identity in its relation to the individual and the involved religions and spiritual traditions. Thus the function of this specific identity for the self is captured first: to enable the positioning in the horizon of the whole life, from which then clear action options for the further life way result. How the spiritual goal is filled, however, depends on different contexts. The extension of the (initially Christian) concept of spirituality to, e.g.,

\footnotetext{
2 On the concept of option, compare the approach of Charles Taylor (2007).

3 Bochinger (1994) has been challenged by Peng-Keller (2014) who underlines contribution of the French catholic lay movement to the new use of the term "Spirituality".
} 
Muslim, Hindu, or Buddhist spirituality, to name only a few, shows possible adaptations. Whether there can also be agnostic or atheistic spiritual identity depends on the narration of the subject using a certain "map of meaning".

A function of spiritual identity is the location of experiences in a system of meaning. The projection surface produced for this can be described as a map of meaning. Experiences give the subject a pictorial idea of the meaning of life as a way of life. Maps of meaning do not simply represent the reality of life 1:1, but receive their specific quality by simplification to the essential. Possible life events are located in their symbolic-spiritual function (birth, death, crisis, decision situations). These "places of meaning" connect through the narrative and relate it to the meaning of life. Each person learns about language, culture, tradition, often also religious maps of meaning, which transmit and explain religious maps of meaning, transmit and explain religious texts and rites, and enable a localization in them.

The interpretation models of reality available to the subject can be thought of as layers or foils of alternating maps of meaning. Contradictory or supplementary elements can thus be assigned to different levels and-if necessary or useful — "leave untouched" and are role- and context-dependent (Burke \& Stets, 2009).

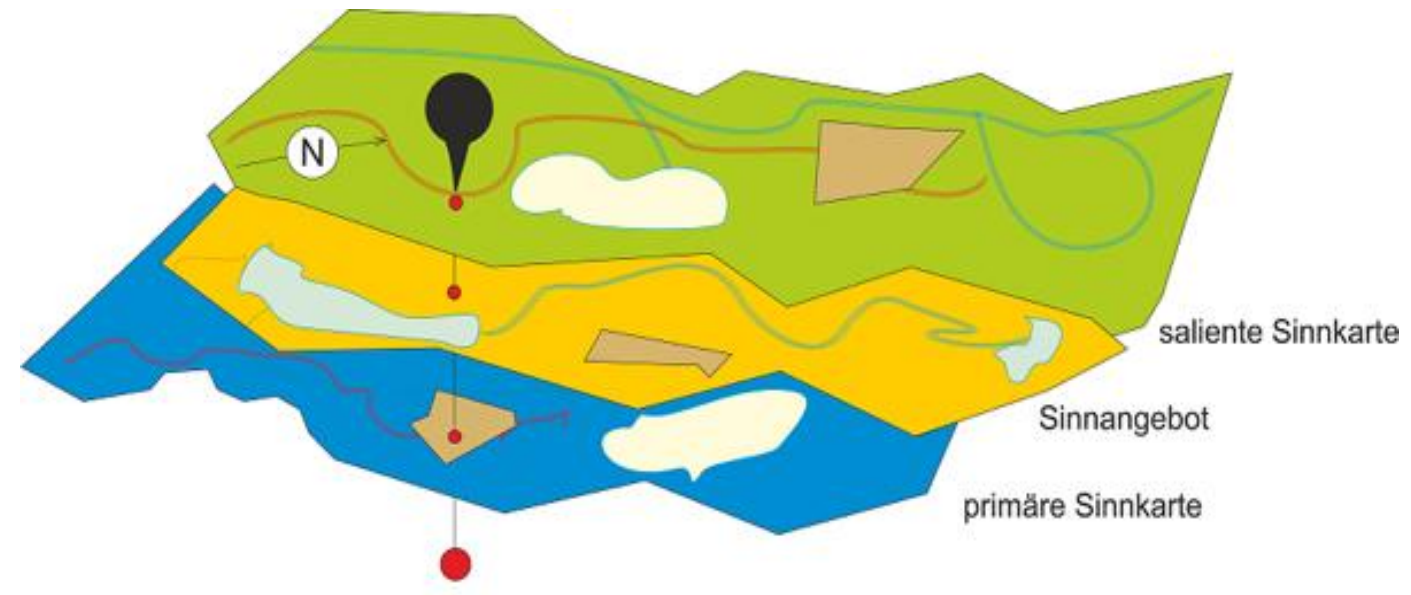

Figure 1. Theoretical model: Spiritual identity as way-of-live navigation.

The theoretical model here would suggest that spiritual identity seeks to synchronize concrete and ultimate meaning, which empirical analysis has confirmed. If a map of meaning, which above all represents $a$ concrete religious tradition, offers no orientation for certain areas of life or experiences, or one that is perceived as inadequate, alternative offers are sought for this case. Thus, for certain "areas of life", alternative maps of meaning can achieve a higher salience than in other areas of life.

Successful spirituality requires a high level of competence in evaluating and dealing with the various maps of meaning. This is the case when the saliente map of meaning can be related by the individual to the experiences of reality in such a way that a navigation corresponding to the map of meaning is possible. The analysis of empirical data suggests that alternative maps of meaning are initially sought in contexts for which the current saliente map of meaning does not offer a satisfactory orientation. At first, different maps of meaning are used depending on the context, or even new maps are completely adopted due to the high degree of orientation. New narratives of the subject "correct" the "error" of the previous maps of meaning.

This identity work, often referred to as conversion in the religious context, leads the self out of the identity crisis through a strong identification with a map of meaning that offers itself as complete. For a phase that can last 
up to 10 or 15 years, it is more difficult for the person concerned to participate in rituals of the religion of origin, such as funerals, etc. (Rötting, 2007). The contents of these rituals must now be combined with the previous experiences of one's own life in a kind of new configuration to create a new life story.

Orthodox meaning maps, whose fascination and postulated universality lies in the "eternally true guidance" and route description, which is often confronted with temporal processes on the basis of "divine origin", hold a hermeneutic challenge: In order for these "eternally true stories" to become functioning meaning maps with reference to lived experience, they need interpretation. This leads to the birth of theologies and hermeneutic traditions of sacred texts. Lyotard has given a succinct expression to the great changes in the role of such traditions by referring to the "end of the great narratives" (Lyotard, Engelmann, \& Pfersmann, 2015).

A divergence between (experienced) reality, one's own position on the map of meaning, and the interpretation offered, leads to disorientation. The theoretical model suggests that a functioning and coherent spiritual identity leads to a happy life. ${ }^{4}$

Interreligious dialogue enables interreligious learning through the networking of connecting points (Rötting, 2007), in which reference points of different maps of meaning are related to each other. In this way, a person's spiritual identity can read, understand and, if necessary, accept alternative maps of meaning.

Religious traditions and organizations have the task of processing the wealth of experience of their tradition as a functioning map of meaning. This does not mean the transmission of rigid teachings or rites, but the passing on of the life experience on which they are based. In a pluralistic world, the absolutizing of a map of meaning leads to radicalism and thus ultimately to violence, because the influence of alternating maps of meaning must be limited. The meaningful handling of alternative cards of meaning and the connection with the ones offered by one's own religious tradition is an existing challenge for religious organizations.

\section{Multiple Religious Belonging-Two Maps?}

There are many ways in which more than one religion can influence identity. A concrete identity also always emerges with the knowledge of other identities. Religions and thus also the religious identities of their relatives emerge in the confrontation with other identities, and in this process of sharing foreign aspects are incorporated into one's own. The History of Religion knows here some examples like Sufi-Jews. ${ }^{5}$ Especial Buddhist-Christian and Jewish-Buddhist exchange processes are often seen in the light of the theological and religious studies debates. Also the emergence of Reform-Judaism can be read as such an exchange process. ${ }^{6}$ Multi-religious identity, however, means more than that influence; it means the simultaneous belonging to different religions. Almost 40 years ago, John B. Cobb, Jr. asked "Can a Christian be a Buddhist, Too?" (Cobb, 1978) and "Can a Buddhist be a Christian, Too?" (Cobb, 1980). The question about the possibility and design of multi-religious identity, however, has only been evident for about fifteen years as a subject for religious studies and theological research. ${ }^{7}$ With Many Mansions? Catherine Cornille lays one of the first detailed discussions with the topic (Cornille, 2002).

\footnotetext{
${ }^{4}$ On the connection between happiness, meaning, and spirituality, Tatjana Schnell points out that an essential factor is the experience of coherence (Schnell, 2016, p. 17), where spirituality plays a very positive role because it can create coherence.

5 See, for example, Paul B. Fenton's comments on Jews and Islamic mysticism, Fenton (2009).

6 Thus Michael A. Meyer sees reform Judaism as an answer to modernity, who got her inspiration from the encounter with Protestantism, how the way in which texts are dealt with or the role of women in American Reform Judaism (Meyer, 2000, p. 538).

7 So far there have been few studies on this subject. For an overview we recommend the work by Rose Drew (2011).
} 
Rose Drew examines very concretely on the basis of empirical interviews (Drew, 2011) with Roger Corless, Sr. Ruth Furneaux, Ruben Habito, John Keenan, Sallie King, and Maria Reis Habito the theological implications for their protagonists, who all describe themselves as multi-religious, but, as Rose Drew shows, there's something different among them.

For Rose Drew, the complexity of the question can already be seen in this that different terms not only point to different things, but can also be used synonymously: This phenomenon has been described as "multireligious identity" and, especially in its more radical forms, as "multiple religious identity", "multiple religious belonging", "hyphenated religious identity", and "bi-religious appurtenance" (Drew, 2011, p. 2). In addition to personal identification with one or more religions influences, the public understanding of nations and religious organizations dealing with the phenomenon is another field of the problem, as Perry Schmidt-Leukel correctly noticed. He points out that in most countries the state regulates the peoples' affiliation to a religious tradition.That's especially true then, when Abrahamic religions are involved. Even the religious ordinance of belonging through vows and rituals, binds in many ways to only one religion. However, the question of multiple religious identity is changing, if one looks at the situation in Asia. Cornille underlines: "[in] the wider history of religion, multiple religious belonging may have been the rule rather than the exception, at least on a popular level" (Cornille, 2002, p. 1f) In India, Nepal, China, Korea, and Japan - to name only a few countries - it is customary that several religions and traditions are active in a person's lifetime. In Korea, for example, Buddhism many shamanistic elements included, shamanism, and Confucianism also shape Buddhism as well as the different Christian denominations. ${ }^{8}$ In Japan it's not uncommon for someone in the course of his or her life to live in different traditions. The difference between East and West is often explained by the different functions, by which religions in Asia accompany, while in the West, the affiliation to one religion is taken for granted, or has been taken for granted. Van Bragt underlines:

multiple belonging is perceived as fundamentally at odds with the traditional understanding of religion. It appears as a deviating state of affairs, set against a presupposed normative pattern: exclusive belonging to a single religion, conceived as a particular system of beliefs in a bounded community. (Bragt, 2002, p. 17)

Multi-religious religious affiliation would therefore be a phenomenon responding to the context of a Western understanding of religion as an innovation and a challenge promoted by a pluralistic society. Michael Amaladoss (2002, p. 306) concretizes here how Drew (2011) underlines that talked about dual affiliation which can be when "people feel called to two religious traditions to be loyal" (Amaladoss, 2002, p. 307). Amaladoss' definition suggests the theoretical possibility that one can unfold the same form of belonging to two religions. Michael von Brück underlines the special importance of the religious tradition ${ }^{9}$ into which someone was born. He probably has in mind the often occurring situation that someone so intensely identified with a second religion later in life that one can speak of multifaith belonging. One special case, however, would be people who are in a bi-religious family and in their religious upbringing both religions have played an important role and therefore have also made it an identification with both traditions. However, there are certainly differences between the religion of the

\footnotetext{
${ }^{8}$ Cf. the study by Hyon Key Kim Hogat on the basis of interviews (Hogarth, 2002). A brief overview in German of the subject offered by Klossek's student research project (Klossek, 2004).

${ }^{9}$ Cf. Drew $(2011$, p. 6): He argues that one's early religious formation "is similar to having acquired a mother tongue (...) [One] may develop later in life multiple religious identities, but the emotional belonging is not the same and the relationship to the respective traditions is different in each case" (Lai \& Brück, 2001, p. 205).
} 
mother and that of the father, which on the one hand may be influenced by the intensity of the religious practice and on the other hand shaped by the different educational responsibility of both parents, agues von Brück.

Certain forms of dialogue seem to have been developed with a view to the Western context to particularly favor multireligiousness. Cornille stresses that Christian-Buddhist and Jewish-Buddhist multi-religious identities are the most common form of this phenomenon in the West (Cornille, 2002, p. 43). Rose Drew points out that in the US context for Buddhist-Jewish Bi-religiosity even exists the already established abbreviation "Jubu" for Jewish Buddhist. Drew also points out that the online groups for Christian-Buddhists have numerous members listed. In her empirical study, Drew points out that multiple belonging is nothing to aspire to, an impression, that can be found by John B. Cobb. ${ }^{10}$ It is rather the case that the individual find themselves in this situation. ${ }^{11}$ Usually one identity remains the more important one. For Knitter, whom Drew also interviewed, this was the Christian one. ${ }^{12}$ John May, in the conference transcript he edited Converging Ways? Conversion and Belonging in Buddhism and Christianity, states that both, the conversion to another religion as well as the turn to a different Religion, without abandoning the first tradition, "in the sense of Bekehrung, changing once religious allegiance, and Umkehr, deepening or rediscovering one's adherence to a particular religious tradition" involves a change of direction and "the possibility of multiple religious belonging" (May, 2007, p. 7).

Michael von Brück compares in his article "A Theory of Multiple Religious Identity" multiple religiosity with bilingualism. In fact it is possible, on the one hand, to speak two languages, even to dream in those languages, but - states Brück - there's still a difference between a learned language and the mother tongue (2007, p. 203). Multiple religious identity needs an intellectual, social, emotional, and institutional basis. Like languages so are religions something learnt at different times and levels. While it is possible to intellectually or socially belong to a new religion, this was emotionally very difficult because of the deep bonds of childhood (Brück, 2007, pp. 199-205). Theologically von Brück expects that multireligiosity can only be achieved and adequately grasped in a pluralistic theology (Brück, 2007, p. 206).

Catherine Cornille's anthology, important for the debate Many Mansions? Multiple Religious Belonging and Christian Identity (Cornille, 2002), suggests that they is the most contributions ${ }^{13}$ focused on the challenge of the Christian understanding of identity and Christian theology. John B. Cobb Jr. underlines in his contribution "Multiple Religious Belonging and Reconciliation" (John B. Cobb Jr. in: Cornille, 2002, p. 27f) that experimenting with multiple affiliation can be good, to advance processes and interreligious learning in religions, but is not a goal in the strict sense of the word. On the contrary it is desirable that the religious traditions about these individuals' new identities can emerge. ${ }^{14}$ Experience and the debate to date about multiple religious identity could work out essential questions on religious and spiritual identity: What does self-identification mean? How does it work if two traditions are involved in the process towards a spiritual identity? Does it have consequences to actively focus on the commonalities, but to also refer to the differences of the religious traditions? How are logical and emotional ruptures between traditions intercepted? Concrete qualitative studies, such as the

10 Those who seek multiple belonging: (Cobb, 2002, p. 25).

11 Cf. Drew, reference to Blée, 1999; Drew, 2011, p. 233, there Note 20.

12 Drew (2011, Note 19). Cf. footnote 21 and Paul Knitter in his this Themea groundbreaking, very autobiographical book Without Buddha I Could Not Be a Christian (Knitter, 2009).

${ }^{13}$ The volume of Cornille (2002) gathers together important theological voices for the Debate. It contributed: Jan van Bragt, John B. Cobb Jr., Joseph S. O'Leary, Franics X. Clooney SJ, Jacques Dupuis SJ, Elisabeth J. Harris, Claude Geffré, Werner G. Jeanrond, and Raimon Panikkar.

${ }^{14}$ Louis T. Albarran comes to an even more cautious assessment in his contribution "Multiple Religious Belonging. Can a Christian Belong to Other Traditions too?” (Albarran, 2007). 
one conducted by Rose Drew (2011) clearly states that multiple religious identity or dual affiliation does not mean that someone has to choose entirely two religious systems to the same extent. Here examples show clearly the very process of identification with the second religion or certain spiritual tradition with an inquiry to the tradition of origin. The actual relationship between the different identities to each other thus creates a new spiritual identity, which is then designated as dual or multiple affiliation. For the theoretical model to be developed, the task is as follows: How does the individual organize in the representation of a spiritual identity the relationship to different religious and spiritual traditions? What does multi-religious belonging do for those who live it? Or, as Rose Drew's study puts it: "dwell in its house"? Rose Drew describes it as an oscillation of the identities; it would also be possible to speak of complementarity.

Both formulations seem to reflect the spiritual identity process in a special way and to keep it in motion before it solidifies and preserves it. This function of spiritual identity is essential for development. Multiple religious identity, which can also be seen as a special form of alternative forms of spirituality that refer to different sources, and indicates the special connections to the respective religious traditions. Thus the question arises: What is a multi-religious identity in comparison to other alternative spiritualities, which also relate to several traditions? What makes it particularly attractive? Or in other words: What is the benefit of spiritual identity in that it's multiple? In Drew's research various remarks can be found that refer to the hold of theological tension which results from the attachment to both traditions and can consequently be made fruitful for the development of spirituality (Drew, 2011, p. 224). So there are different theoretical views on how multiple belonging affects the spiritual identity: Michael von Brücks view suggests two, but different related identities. Rose Drew describes this relation as oscillation.

My own research (Rötting, 2019b) suggests that there are "reasons of navigation" that urge someone to use two maps and keeps them as part of the salient map as double-identity. One example is Frieder $\mathrm{C}^{15}$, who states that he was educated "Christian", but later developed an interest in different forms of faith and spirituality, especially Zen-Buddhism:

I must also say that most of them are still quite conventional for my feelings. With the personal conception of God and corresponding wishes and prayers. They already called me a Buddhist. Maybe that's not quite true. Maybe the Christians call me a Buddhist and the Buddhists call me a Christian. ${ }^{16}$ (M9, Frieder C., 3.1)

The presumed attribution in the last sentence of the quotation is not at any point in rejected the interview. This is where Rose Drew in her pioneering work showed oscillation between religious identities, which she calls bifurcation (Drew, 2011, p. 211). This apparently deliberately maintained a tension between the maps of meaning, allowing a deeper penetration to possibly occur later when a saliente pattern can be lifted.

We find different "reasons" which people express in the narratives they tell. Among the conducted $(n=80)$ interviews on spiritual identity in Munich, Vilnius, Seoul, New York, some indicated a form of Buddhist-Christian multiple belonging $(n=6)$. Among them also some $(n=4)$ named themselves as "Jubus" (Jewish Buddhists), a term which became famous after many converts to Buddhism also related to their own

\footnotetext{
15 All examples are taken from Rötting (2019b), here p. 235. All interviewed people have agreed to publication and where given the possibility to use a pseudonym to protect their privity.

16 Original: "Ich muss auch sagen, die meisten dort sind für mein Gefüh doch noch recht konventionell geprägt. Mit der persönlichen Gottesvorstellung und entsprechenden Wü̈schen und Gebeten. Mich ham sie ja schon als Buddhist bezeichnet. Das stimmt vielleicht auch nicht ganz. Vielleicht ist es so, dass die Christen mich Buddhist nennen und die Buddhisten mich Christ nennen würden".
} 
Jewishness. But their spiritual framing and rooting in Buddhism and Judaism is different in each single case.

Among those who indicated a form of dual belonging, five different types can befound:

1. Multiple belonging without strong relation to one tradition;

2. Conversion with strong relation to primal identity;

3. Multiple relation without giving up primal identity;

4. Relation to more traditions without a identity in one of them;

5. Opening of primal tradition.

Due to the lack of space it is only possible here to describe these types with some examples.

1. Multiple belonging without strong relation to one tradition: Tanja M. grows up without intensive reference to Catholicism, but discovers it as a teenager through an aunt. Later she identifies with Yoga, Sufism, and Judaism, each for different reasons (M1, Tanja M. ${ }^{17}$ ).

2. Conversion with strong relation to primal identity: Hyon Gak is born in a strong Irish-Catholic family in New York. Later, he discovered the Zen way for himself and becomes a monk. In his dharma talks and in his thinking there are theological and emotional references to Christianity, of which he says that he is now actually realizing it in his own way (M5, Hyon Gak; others examples: NYC9, Matt).

3. Multiple relation without giving up primal identity: Multiple affiliation without abandoning the identity of origin: Without leaving Christianity, but with a strong change of the image of God and strong sympathy for Buddhism Frieder C. plays with both of these identities (M9, Frieder C., also: VLN14, Michaelis; NYC20, Chaz).

4. Relation to more traditions without a identity in one of them: A relation to any single tradition is rejected, but there are points of connection and linking points of contact in terms of inspiration and learning ${ }^{18}$ with more spiritual traditions (M14, Julia M.; M15, Gabi S.; M16, Deva).

5. Opening of primal tradition: Choosing a tradition, then widening: One example here is Nick, who is of Jewish secular background. He first discovered the Zen way and identified with it. In a special Christ-experience, so he narrated, he understood from his perspective that Christ is the perfect love and it's good that it can be accepted. He does not know whether this is the view of the Christians, but he had this view-of-Christ in such a way (NYC5, Nick G.).

The analyses of the interviews of dual-belongers among the group indicate that secularity in society is an important aspect to help in developing "space" for multiple belonging. But there are different reasons for mixed navigation maps: Cultural, emotional, and also philosophical can be identified in the identity sets and the anamorphic point. Also dual identity is created by one story that creates a life-way-navigation-system. But what about the spiritual identity of dual belongers? Anamorphosis, a optical term (gr: morphe, form, "Gestalt", used in art by Caspar Schott), is a distorted image where the viewer must use special devices or be in a specific place to see the image undistorted. We can call spiritual anamorphosis a perspective created with usage of identity sets, by refiguration that gives a full, undistorted "Gestalt" of one's life-way-navigation. So how do dual or multiple spiritual identities crates "Gestalt"? Is "Multiple Identity" a way or goal? Does multiple identity help to create identity sets that allow a spiritual anamophosis, or are there reasons for individuals to prefer an oscillation (Drew)?

\footnotetext{
${ }^{17}$ In my study (Rötting, 2019b) are more detailed examples and analysis of these cases. The indication number gives the venue of an Interview $(\mathrm{M}=$ Munich, $\mathrm{NYC}=\mathrm{New}$ York, $\mathrm{VNO}=$ Vilnius, and $\mathrm{S}=\mathrm{Seoul})$, followed by a number and the Pseudonym or name given by the interviewed person. Interviews mentioned here can in this way be found in their full description in the study.

${ }^{18}$ Linking points of contact play a very important role in inter religious learning processes. See Rötting, 2007.
} 
The analysis of the interview samples suggest that the oszillisation between and with two identity sets is a anamorphic spiritual identity by itself, communicating a process of cultural images (e.g., B/C or J/B) which help those who hold a multiple identity best to navigate their spiritual path. One might be reminded of real live navigation where we, e.g., look at weather and road maps on our travel. In the same way the oszillization of two maps in dual belonging seems to highlight different aspects of a spiritual life-way-navigation and corresponding world views.

The comparison of the structures of the narratives and those described in salient maps of the life-way-navigation shows that the form of multiple belonging strongly depends on the primary map but also on social acceptance. Primary maps of meaning that were created in a strongly secular context even though at the same time with strong visual identity, rather allow for a multiple belonging. The presented cases indicate that this is favoured by two factors: Societies influenced by the secular factor accept freedom of religion and also "special ways", secondly, this secular framework also offers a level of discourse, for example on ethical issues allowing different traditions to meet without conflict.

\section{References}

Albarran, L. T. (2007). Community identity. Dynamics of religion in context. In S. C. H. Kim \& P. Kollontai (Eds.). London: T \& T Clark.

Amaladoss, M. (2002). Double religious belonging and liminality: An anthropological reflection. East Asian Pastoral Review, 39, 292-312.

Berger, P. L. (2015). Many altars of modernity: Toward a paradigm for religion in a pluralist age. Boston, Berlin: De Gruyer.

Bochinger, C. (1994). New age und moderne religion. Religionswissenschaftliche Analysen. Gütersloh: Chr. Kaiser, Gütersloher Verlagshaus.

Bruck, M. (2007). A theory of multiple religious identity. In J. A. May (Ed.), Converging ways (pp. 181-206). St. Ottilien: EOS Verlag.

Bragt, J. (2002). Multiple religious belonging of the Japanese people. In C. Cornille (Ed.), Many mansions? Multiple religious belonging and Christian identity (pp. 7-19). New York: Maryknoll.

Burke, P. J., \& Stets, J. E. (2009). Identity theory. Oxford: Oxford University Press.

Cobb, J. B. (1978). Can a Christian be a Buddhist, too? Japanese Religions, 10, 1-10.

Cobb, J. B. (1980). Can a Buddhist be a Christian, too? Japanese Religions, 11, 35-55.

Cobb, J. B. (2002). Multiple religious belonging and reconciliation. In C. Cornille (Ed.), Many mansions? Multiple religious belonging and Christian identity (pp. 20-28). New York: Orbis.

Cornille, C. (Ed.). (2002). Many mansions? Multiple religious belonging and Christian identity. Maryknoll, New York: Orbis.

Drew, R. (2011). Buddhist and Christian? An exploration of dual belonging. London: Routledge.

Fenton, P. B. (2009). Judische und islamische Mystik. München: Books Ex Oriente.

Hogarth, H. K. (2002). Syncretism of Buddhism and Shamanism in Korea, Korean studies series. Seoul: Jimoondang Publishing Company.

Keupp, H. (Ed.). (1999). Identitatskonstruktionen. Das Patchwork der Identitaten in der Spatmoderne. Hamburg: Rowohlt-Taschenbuch-Verlag.

Klossek, R. (2004). Schamanismus und Buddhismus in Korea. München: GRIN Verlag.

Lyotard, J. F., Engelmann, P., \& Pfersmann, O. (2015). Das postmoderne Wissen: Ein Bericht, Passagen forum. Wien: Passagen Verlag $\mathrm{GmbH}$.

May, J. A. (Ed.). (2007). Converging ways? Conversion and belonging in Buddhism and Christianity. St. Ottilien: EOS Verlag, St. Ottilien.

Meyer, M. A. (2000). Antwort auf die Moderne: Geschichte der Reformbewegung im Judentum. Weimar: Bohlau.

Peng-Keller, S. (2014). Herkunft des Spiritualitätsbegriffs. Spiritual Care, 1, 36-47.

Ricoeur, P. (1988). Zeit und historische Erzahlung, Zeit und Erzahlung. Paderborn: Fink. 
Rötting, M. (2007). Interreligioses Lernen im buddhistisch-christlichen Dialog. Lerntheoretischer Zugang und qualitative Studie in Deutschland und Sudkorea. St. Ottilien: EOS Verlag.

Rötting, M. (2019a). Navigation! Spirituelle Identität in einer interreligiösen Welt. Feldforschung in München, Vilnius, Seoul und New York. St. Ottilien: EOS Pulication.

Rötting, M. (2019b). Navigation. Spirituelle Identität in einer interreligiösen Welt. Feldforschung in München, Vilnius, Seoul und Südkorea. St. Ottilien: EOS Pulication.

Schnell, T. (2016). Psychologie des Lebenssinns. Berlin, Heidelberg: Springer.

Taylor, C. (2007). A secular age. Cambridge: Harvard University Press. 